$\begin{array}{r}\text { Phinisi Integration Review } \\ \text { Vol. 2, No.2, Agustus 2019 Hal 338-347 } \\ \text { Website: } \underline{\text { http://ojs.unm.ac.id/pir }} \\ \text { p-ISSN: 2614-2325 dan e-ISSN: } 2614-2317 \\ \text { DOI: https://doi.org/10.26858/pir.v2i2.10088 } \\ \hline\end{array}$

\title{
Mekanisme Pertanggungjawaban Terhadap Objek Gadai Nasabah Oleh PT. Pegadaian Cabang Panakkukang Kota Makassar
}

\author{
Muhammad Zainal Abidin \\ Pascasarjana Universitas Negeri Makassar, Indonesia \\ Email: muhzaenal580@gmail.com
}

\begin{abstract}
Abstrak. Tujuan penelitian ini adalah untuk mengetahui dan menganalisa tentang pelaksanaan tanggung jawab PT. Pegadaian (Persero) dalam hal terjadi kerusakan atau kehilangan barang yang dijaminkan dalam perjanjian kredit dengan jaminan gadai di PT. Pegadaian Cabang Panakkukang Kota Makassar. Hasil penelitian menunjukan bahwa PT. Pegadaian (Persero) bertanggung jawab untuk menanggung resiko dalam hal terjadi kerugian yang dialami nasabah atas barang jaminan gadai yang dititipkan. Hal tersebut memang seharusnya dilakukan karena dalam perjanjian gadai barang jaminan berada dalam kekuasaan PT. Pegadaian (Persero). Resiko yang di tanggung PT. Pegadaian adalah tidak termasuk yang ditimbulkan karena Force Majeur. Upaya hukum yang ditempuh oleh nasabah jika terjadi wanprestasi dari PT. Pegadaian (Persero) adalah menyelesaikan sengketa melalui jalur musyawarah. Tetapi jika dengan musyawarah tidak selesai, maka persengketa ini dapat dilakukan melalui lembaga mediasi untuk mendapatkan solusi yang baik. Bila jalur mediasi tidak juga mendapatkan hasil, maka jalur paling akhir yang harus ditempuh adalaha jalur pengadilan. Untuk pemeliharaan objek gadai nasabah, PT. Pegadaian Cabang Panakkukang Kota Makassar memisahkan barang yang berbeda pada tempat yang berbeda berdasarkan nilai ekonomisnya, melakukan perawatan yang berbeda, dilakukan pengecekan dan pembersihan beberapa kali seminggu. Umumnya sudah diatur dalam buku pedoman PT. Pegadaian (Persero)
\end{abstract}

Kata kunci: Tanggung jawab, Perjanjian Kredit, Jaminan Gadai

\begin{abstract}
The Responsibility Mechanism On Customer Pawn Object by PT. Pawnshop Of Panakkukang Branch In Makassar City (supervised by Anwar Ramli and Darman Manda). The purposes of this research are to examine and analyze on the implementation of responsibility of PT. Pawnshop in terms of damage or loss of goods pledged in a credit agreement by guaranteed mortgage at PT. Pawnshop of Panakkukang Branch In Makassar City. The type of this research is qualitative research. Tecniques of collecting the data are interview, observation, and documentation. While, tecniques of analyzing the data are conducted through data reduction, data display, and conclusion drawing. The results of this research reveal that PT. Pawnshop is responsible for taking risks in the loss experienced by the customer for the mortgage guaranteed. This should be done because in mortgage agreement the collateral is in the power of PT. Pawnshop. The risks posed are due to force majeure. Legal efforts will be taken by the customer if there is a default from PT. Pawnshop is by resolving the disputes through deliberation. However, if the deliberation is not finished, this dispute can be done through a mediation institution to obtain good solutions. If the mediation path does not also get satisfying results, then the last path that must be taken is through the court. For the maintenance of customer pledge objects, PT. Pawnshop Of Panakkukang Branch In Makassar City separates different goods in different places based on their economic value, do different treatments, do the
\end{abstract}


checking and cleaning several times a week. Generally, it has been arranged in the guidance book of PT. Pawnshop.

Keywords: Responsibility, Credit Agreement, Guaranteed Mortgage.

Ini adalah artikel dengan akses terbuka dibawah licenci CC BY-NC-4.0

(https://creativecommons.org/licenses/by-nc/4.0/ )

\section{PENDAHULUAN}

Salah satu alternatif yang aman untuk meminjam uang adalah pada Bank pemerintah/swasta maupun pada lembaga keuangan non perbankan, misalnya PT. Pegadaian. Sebagai lembaga pemerintah dibawah naungan Departemen Keuangan, yang merupakan lembaga perkreditan tertua di Indonesia dan sudah dikenal secara luas oleh masyarakat golongan ekonomi lemah. Kesederhanaan PT. Pegadaian (Persero) dalam menyalurkan kredit dilakukan dengan jaminan benda bergerak yang disebut dengan gadai. Gadai secara umum diatur dalam Kitab Undangundang Hukum Perdata, yaitu Buku II Pasal 1150 sampai dengan pasal 1160.

Selain berbeda dengan KUHPerdata, pengertian gadai menurut syariat Islam juga berbeda dengan pengertian gadai menurut hukum adat yang mana dalam ketentuan hukum adat pengertian gadai yaitu menyerahkan tanah untuk menerima pembayaran sejumlah uang secara tunai, dengan ketentuan si penjual (penggadai) tetap berhak atas pengembalian tanahnya dengan jalan menebusnya kembali (Antonio, 2001:159).

Dapat diketahui bahwa gadai adalah suatu hak yang memberikan kepada kreditur pelunasan yang mendahulukan dari krediturkreditur lainnya. Gadai adalah suatu perjanjian riil, sebagaimana ditentukan dalam pengertian gadai itu sendiri, gadai hanya ada manakala benda yang akan digadaikan secara fisik telah dikeluarkan dari kekuasaan pemberi gadai.

PT. Pegadaian merupakan salah satu dari lembaga keuangan non-bank di Indonesia yang ditangani oleh pemerintah di bawah naungan Kementerian Keuangan, yang melakukan jasa pemberian pinjaman uang/kredit kepada masyarakat dengan cara menguasai benda/barang yang digadaikan oleh nasabah dan setelah dilakukan penaksiran harga tersebut maka nasabah dapat langsung menerima pinjaman uang dari barang yang digadaikan tersebut. Dan apabila telah jatuh tempo pinjaman yang diperoleh tidak dikembalikan, maka barang jaminan tersebut dapat dijual/dilelang guna menutup pengembalian pinjaman dan jika masih ada nilai sisanya maka akan dikembalikan kepada nasabah.

Gadai merupakan salah satu kegiatan ekonomi yang dilandasi oleh beberapa faktor, terutama kebutuhan, baik yang mendesak maupun tidak berupa; barang, jasa, uang, emas dan lain sebagainya. Di Indonesia telah banyak menyebar Pegadaian-pegadaian baik di Kota maupun Kabupaten. Terdapat beberapa program yang ada di PT. Pegadaian, seperti halnya menggadaikan barang berharga untuk mendapatkan sebuah pinjaman uang, program tabungan emas, cicil emas batangan dan lain sebagainya. Bahkan ada sebuah semboyan dari PT. Pegadaian yakni mengatasi masalah tanpa masalah, tentu dengan adanya hal tersebut pastinya kehadiran PT. Pegadaian adalah untuk membantu masyarakat dan melayani masyarakat untuk mengatasi permasalahan yang mereka miliki.

Dalam Pasal 1150 Kitab Undang-Undang Hukum Perdata yang berbunyi "Gadai adalah suatu hak yang diperoleh seseorang berpiutang atas suatu benda bergerak, yang diserahkan kepadanya oleh seorang berhutang atau orang lain atas namanya, dan yang memberikan kekuasaan kepada si berpiutang untuk mengambil pelunasannya dari barang tersebut secara didahulukan daripada orang berpiutang lainnya, dengan pengecualian biaya untuk melelang barang tersebut dan biaya yang telah dikeluarkan untuk menyelamatkannya, setelah barang itu digadaikan biaya-biaya mana yang harus didahulukan.

Lebih lanjut Menurut Peraturan Pemerintah Republik Indonesia Nomor 178 tahun 1961 tentang Pendirian Perusahaan Negara Pegadaian pasal 6 yaitu "Perusahaanperusahaan dalam lapangan perkreditan atas dasar hukum gadai dengan tanggungan barangbarang bergerak dengan cara yang mudah, cepat, 
dan aman, sehingga dengan demikian ikut serta mencegah adanya lintah darat, ijon, Pegadaian gelap dan praktek riba lainnya.

Hadirnya PT. Pegadaian sebagai sebuah lembaga keuangan formal di Indonesia yang bertugas menyalurkan pembiayaan dalam bentuk penyaluran pinjaman kepada masyarakat yang membutuhkan berdasarkan hukum gadai. Ini merupakan solusi yang baik, sebab dengan adanya lembaga PT. Pegadaian tersebut diharapkan dapat membantu masyarakat agar tidak terjerat dengan praktek-praktek lintah darat.

Pemberian kredit gadai merupakan pemberian pinjaman berdasarkan hukum gadai dengan prosedur pelayanan yang cepat, sederhana dan mudah. Gadai sebagai salah satu kategori dari perjanjian utang-piutang, untuk suatu kepercayaan dari kreditur, maka debitur menggadaikan barangnya sebagai jaminan terhadap utangnya itu. Barang yang dijadikan jaminan tersebut pada dasarnya tetap milik orang yang menggadaikan, namun dikuasai oleh penerima gadai.

Mendapatkan pinjaman maka nasabah harus mengikuti prosedur yang telah ditetapkan oleh pihak PT. Pegadaian. Nasabah yang datang ke kantor PT. Pegadaian terlebih dahulu untuk memperoleh penjelasan tentang Pegadaian, kemudian nasabah membawa barang jaminan sebagai agunan kepada pihak penerima gadai (murtahin) untuk diperiksa barang tersebut kemudian ditaksir nilai jaminan yang diberikan sesuai dengan harga yang berlaku di pasaran. Setelah nilai taksir ditetapkan langkah selanjutnya adalah menentukan jumlah pinjaman beserta sewa modal yang dikenakan dan kemudian diinformasikan kepada calon nasabah untuk membuat kesepakatan.

Bentuk barang yang akan dijadikan sebagai jaminan tersebut adalah barang-barang yang memenuhi syarat dan hukum gadai. Barang gadai tersebut terdiri dari beberapa yaitu: emas, berlian, kendaraan, barang elektronik, BPKB kendaraan (benda yang dapat bergerak) dan lainlain.

Barang jaminan tersebut dikuasai oleh pihak PT. Pegadaian dan disimpan di dalam gudang. Permasalahan adalah barang jaminan tersebut dalam penyimpanannya disamakan. Emas atau surat berharga tidak terdapat permasalahan jika hanya disimpan dalam gudang atau tempat penyimpanan khusus. Namun barang jaminan berupa televisi, laptop dan lain sebagainya, tentu berbeda. Barang jaminan berupa televisi, laptop dan lain-lain membutuhkan penjagaan sekaligus perawatan secara intensif, baik bagian luar maupun bagian dalam mesin.

Permasalahan yang kadang terjadi adalah kemungkinan pada waktu pelunasan terhadap kredit, barang jaminan berupa benda bergerak yang akan diambil oleh pemberi gadai (nasabah) ternyata rusak ataupun hilang, misalnya disebabkan karena terbakar, atau kelalaian petugas dalam menjaga dan merawat barang gadai milik nasabah yang menyebabkan kerugian bagi pemberi gadai (nasabah) yang bersangkutan, padahal yang tertera pada poin empat tentang misi PT. Pegadaian yaitu; Aman (barang yang digunakan sebagai jaminan akan di jaga dengan baik tanpa ada kerusakan yang berarti).

Selain dari hilang atau rusaknya barang nasabah, hal lain juga pernah terjadi adalah tertukarnya barang milik nasabah. Hal ini disebabkan oleh kelalaian yang dilakukan oleh petugas atau karyawan dalam pemiliharaan dan proses transaksi yang dilalukakan sebelumnya. Berdasarkan uraian diatas, maka penulis tertarik mengadakan suatu penelitian dengan judul; "Mekanisme Pertanggung Jawaban Terhadap Objek Gadai Nasabah Oleh PT. Pegadaian Cabang Panakkukang Kota Makassar".

\section{Mekanisme Tanggung Jawab}

Menurut Kadir (2000) teori tanggung jawab dalam perbuatan melanggar hukum (tort liability) dibagi menjadi beberapa teori yaitu:

a) Tanggung jawab akibat perbuatan melanggar hukum yang dilakukan dengan sengaja, tergugat harus sudah melakukan perbuatan sedemikian rupa sehingga merugikan penggugat atau mengetahui bahwa apa yang dilakukan tergugat akan mengakibatkan kerugian.

b) Tanggung jawab akibat perbuatan melanggar hukum yang dilakukan karena kelalaian, didasarkan pada konsep kesalahan yang berkaitan dengan moral dan hukum yang sudah bercampur baur.

c) Tanggung jawab mutlak akibat perbuatan melanggar hukum tanpa mempersoalkan kesalahan, didasarkan pada perbuatan baik secara sengaja maupun tidak sengaja, artinya meskipun bukan kesalahanya tetap bertanggung jawab atas kerugian yang timbul akibat perbuatannya.

Menurut Munir Fuady, (1997) Ada 5 bentuk mekanisme tanggung jawab yaitu: 
a) Tanggung jawab berdasarkan unsur kesalahan. Teori ini menyatakan bahwa seorang baru dapat dimintakan pertanggungjawaban secara hukum jika ada unsur kesalahan yang diberlakukannya.

b) Praduga untuk selalu bertanggung jawab; Teori ini menyatakan bahwa tergugat selalu dapat dianggap bertanggung jawab sampai ia dapat membuktikan bahwa ia tidak bersalah.

c) Praduga untuk tidak selalu bertanggung jawab; Teori ini adalah kebalikan dari prinsip yang kedua, dimana pelaku usaha tidak dapat diminta pertanggungjawabanya dan konsumenlah yang menanggung segala resiko. Teori praduga untuk tidak bertanggung jawab hanya dikenal dalam lingkup transaksi konsumen yang sangat terbatas.

d) Tanggung jawab mutlak; Teori tanggung jawab mutlak dalam hukum perlindungan konsumen secara umum digunakan untuk meminta pertanggungjawaban pelaku usaha yang memasarkan produknya yang merugikan konsumen. Asas tanggung jawab ini lebih dikenal dengan nama product liability.

e) Tanggung jawab dengan pembatas; Teori ini sangat merugikan konsumen bila ditetapkan secara sepihak oleh pelaku usaha. Seharusnya pelaku usaha tidak boleh secara sepihak menentukan klausula yang merugikan konsumen, termasuk membatasi maksimal tanggung jawabnya. Jika ada pembatas mutlak harus berdasarkan perundang-undangan yang berlaku.

Tanggung jawab timbul karena adanya hubungan antara keduanya, tetapi terdapat tanggung jawab masing-masing. Atas dasar keterkaitan yang berbeda maka salah satu pihak melakukan kontak dengan yang lainnya dengan tujuan tertentu yaitu mendapatkan keuntungan yang sebesar-besarnya dengan peningkatan produktifitas dan efisiensi. Sedangkan nasabah hubungannya untuk memenuhi tuntutan kebutuhan hidup.

Dari beberapa teori kajian mekanisme pertanggungjawaban tersebut dapat di simpulkan bahwa mekanisme tanggung jawab dalam sebuah transaksi, menjadi tolak ukur dalam kualitas pelayanan kepada publik, terutama yang berkaitan dengan permasalahan penitipan barang jaminan, seperti yang diberlakukan oleh PT. Pegadaian dalam memperdayakan nasabah. Pelayanan jaminan keamanan yang diberikan PT. Pegadaian menjadi sangat penting untuk meningkatkan kepercayaan masyarakat atau pihak yang berhubungan langsung dengan PT. Pegadaian.

\section{Pegadaian}

Susilo (1999) pengertian pegadaian adalah suatu hak yang diperoleh seseorang yang mempunyai piutang atas suatu barang bergerak. Barang bergerak tersebut diserahkan kepada orang yang berpiutang oleh seorang yang mempunyai utang.

Jadi dapat disimpulkan bahwa gadai adalah suatu hak yang diperoleh oleh orang yang berpiutang atas suatu benda bergerak yang diberikan oleh orang yang berpiutang sebagai suatu jaminan dan barang tersebut bisa dijual jika orang yang berpiutang tidak mampu melunasi utangnya pada saat jatuh tempo. Sedangkan pengertian Perusahaan Umum Pegadaian adalah suatu badan usaha di Indonesia yang secara resmi mempunyai izin untuk melaksanakan kegiatan lembaga keuangan berupa pembiayaan dalam bentuk penyaluran dana ke masyarakat atas dasar hukum gadai.

Menurut Pasal 1150 Kitab UndangUndang Hukum Perdata yang berbunyi "Gadai adalah suatu hak yang diperoleh seseorang berpiutang atas suatu benda bergerak, yang diserahkan kepadanya oleh seorang berhutang atau orang lain atas namanya, dan yang memberikan kekuasaan kepada si berpiutang untuk mengambil pelunasannya dari barang tersebut secara didahulukan dari pada orang berpiutang lainnya, dengan pengecualian biaya untuk melelang barang tersebut dan biaya yang telah dikeluarkan untuk menyelamatkannya, setelah barang itu digadaikan biaya-biaya mana yang harus didahulukan.

Sedangkan Gadai menurut Kitab UndangUndang Hukum Perdata (Burgenlijk Wetboek) Buku II Bab XX Pasal 1150, adalah suatu hak yang diperoleh seseorang berpiutang atas suatu barang bergerak, yang diserahkan kepadanya oleh seseorang yang berhutang atau oleh orang lain atas namanya dan yang memberikan kekuasaan kepada si berpiutang itu untuk mengambil pelunasan dari pada orang-orang yang berpiutang lainnya, dengan pengecualian biaya untuk melelang barang tersebut dan biayabiaya mana yang harus didahulukan.

Selain berbeda dengan KUHPerdata, pengertian gadai menurut syariat Islam juga berbeda dengan pengertian gadai menurut hukum adat yang mana dalam ketentuan hukum adat pengertian gadai yaitu menyerahkan tanah 
untuk menerima pembayaran sejumlah uang secara tunai, dengan ketentuan si penjual (penggadai) tetap berhak atas pengembalian tanahnya dengan jalan menebusnya kembali (Antonio, 2001:159).

Dari uraian diatas, dapat disimpulkan bahwa pegadaian adalah suatu hak yang diperoleh oleh orang yang berpiutang atas suatu barang yang bergerak yang diserahkan oleh orang yang berpiutang sebagai jaminan utangnya dan barang tersebut dapat dijual oleh yang berpiutang bila yang berutang tidak dapat melunasi kewajibannya pada saat jatuh tempo.

\section{Dasar Hukum Pegadaian}

Dalam Pasal 1150 Kitab Undang-Undang Hukum Perdata yang berbunyi "Gadai adalah suatu hak yang diperoleh seseorang berpiutang atas suatu benda bergerak, yang diserahkan kepadanya oleh seorang berhutang atau orang lain atas namanya, dan yang memberikan kekuasaan kepada si berpiutang untuk mengambil pelunasannya dari barang tersebut secara didahulukan daripada orang berpiutang lainnya, dengan pengecualian biaya untuk melelang barang tersebut dan biaya yang telah dikeluarkan untuk menyelamatkannya, setelah barang itu digadaikan biaya-biaya mana yang harus didahulukan.

Berdasarkan rumusan yang diberikan tersebut dapat diketahui bahwa untuk dapat disebut gadai, maka unsur-unsur dibawah ini harus dipenuhi:

1. Gadai diberikan hanya atas benda bergerak.

2. Gadai harus dikeluarkan dari penguasaan pemberi gadai.

3. Gadai memberikan hak kepada kreditur untuk memperoleh pelunasan terlebih dahulu atas piutang kreditur (droit de preferent).

4. Gadai memberikan kewenangan kepada kreditur untuk mengambil sendiri pelunasan secara mendahului tersebut.

Gadai sebagai suatu hak yang mendahulukan dari seorang kreditur untuk memperoleh pelunasan piutangnya, sebagaimana diatur dalam pasal 1133 KUHPerdata mengenai hak untuk diterlebih dahulukan diantara para kreditur terbit dari hak istimewa, dari gadai, dan dari hipotek, Sedangkan Pasal 1134 KUHPerdata "Hak istimewa ialah suatu hak yang oleh UndangUndang diberikan kepada seorang kreditur sehingga tingkatannya lebih tinggi daripada kreditur lainnya, semata-mata berdasarkan sifat piutangnya. Gadai dan hipotek adalah lebih tinggi daripada hak istimewa, kecuali dalam halhal dimana oleh Undang-Undang ditentukan sebaliknya."

Berdasarkan rumusan kedua Pasal tersebut maka dapat diketahui bahwa gadai adalah suatu hak yang memberikan kepada kreditur pelunasan yang mendahulukan dari kreditur-kreditur lainnya. Gadai adalah suatu perjanjian riil, sebagaimana ditentukan dalam pengertian gadai itu sendiri, gadai hanya ada manakala benda yang akan digadaikan secara fisik telah dikeluarkan dari kekuasaan pemberi gadai.

Pengeluaran benda yang digadaikan dari pemberi gadai ini bersifat mutlak dan tidak dapat ditawar-tawar. Pengeluaran benda yang digadaikan dari kekuasaan pemberi gadai ini dapat dilakukan, baik dengan menyerahkan kekuasaan atas benda yang digadaikan tersebut kepada kreditur atau pihak ketiga, untuk kepentingan kreditur, sebagai pemegang gadai. Kesepakatan untuk memberi gadai tidak dengan begitu saja melahirkan gadai, melainkan sampai perbuatan pengeluaran benda gadai dari kekuasaan debitur atau pemberi gadai dilakukan (Kartini \& Gunawan, 2006:77).

Dalam Pasal 1152 KUHPerdata "Hak gadai, atas benda bergerak dan atas piutangpiutang bahwa diletakkan dengan membawa barang gadainya dibawah kekuasaan kreditur atau seorang pihak ketiga, tentang siapa telah disetujui oleh kedua belah pihak. Tak salah adalah hak gadai atas segala benda yang dibiarkan tetap dalam kekuasaan kreditur." Hak gadai hapus, apabila barang gadainya keluar dari kekuasaan penerima gadai. Apabila namun barang tersebut hilang dari tangan penerima gadai ini atau dicuri dari padanya, maka berhaklah ia menuntutnya kembali, sebagaimana disebutkan dalam Pasal 1977 ayat kedua, sedangkan apabila barang gadai didapatkan kembali, hak gadai dianggap tidak pernah hilang. Hal tidak berkuasanya pemberi gadai untuk bertindak bebas dengan barang gadainya, tidaklah dapat dipertanggungjawabkan kepada kreditur yang telah menerima barang tersebut dalam gadai, dengan tak mengurangi hak yang kehilangan atau kecurian barang itu, untuk menuntutnya kembali."

Maka tujuan penelitian ini adalah sebagai berikut:

1) Mendeskripsikan mekanisme tanggung jawab objek gadai nasabah di PT. Pegadaian Cabang Panakkukang Kota Makassar 
2) Mengidentifikasi pemeliharaan objek gadai nasabah di PT. Pegadaian Cabang Panakkukang Kota Makassar.

\section{METODE PENELITIAN}

Jenis penelitian ini tergolong dalam penelitian kualitatif yang menguraikan hal-hal yang bersifat alamiah dari penafsiran sebuah fenomena, menurut Moleong (2014:4) penelitian kualitatif yaitu penelitian yang menghasilkan data deskriptif berupa kata-kata tertulis atau lisan dari orang-orang dan prilaku yang dapat diamati. Pendekatan ini diarahkan pada latar dan individu tersebut secara holistik (utuh). Penelitian ini menggunakan pendekatan deskriptif yang benar-benar hanya memaparkan apa yang terdapat atau terjadi dalam sebuah kancah lapangan atau wilayah tertentu.

\section{Teknik Pengumpulan Data}

1) Wawancara

Wawancara adalah percakapan dengan maksud tertentu. Percakapan itu dilakukan oleh dua pihak, yaitu pewawancara yang mengajukan pertanyaan dan yang diwawancarai yang memberikan jawaban atas pertanyaan itu (Moleong, 2014:186).

2) Pengamatan (Observasi)

Observasi adalah pengamatan dan pencatatan secara sistematis terhadap berbagai fenomena yang diteliti dan melibatkan interaksi intensif antara peneliti dengan objek yang diteliti. Observasi diartikan sebagai pengamatan dan pencatatan secara sistematik terhadap gejala yang tampak pada objek penelitian.

3) Dokumentasi

Teknik

dokumentasi adalah mengumpulkan data dengan cara mencatat mendokumentasikan informasi dari tempat yang diteliti melalui peninggalan tertulis, seperti arsip-arsip dan termasuk juga buku-buku tentang pendapat, teori, dalil atau hukum-hukum, dan lain-lain yang berhubungan dengan masalah penelitian.

\section{Analisis Data}

Kegiatan dalam menganalisis data yaitu mengelompokkan data berdasarkan variabel dan jenis responden, mentabulasi data variabel yang diteliti, melakukan perhitungan untuk menjawab rumusan masalah dan melakukan perhitungan untuk menguji hipotesis yang telah diajukan (Sugiyono, 2013:207). Menurut Milles Matthew
B dan Michael Hubberman (1992) ada tiga teknik dalam menganalisis data, sebagai berikut:

1) Reduksi Data

Reduksi data merupakan bentuk analisis yang menajamkan, menggolongkan, mengarahkan, membuang yang tidak perlu, dan mengorganisasi data dengan cara tertentu sehingga simpulan akhir dapat ditarik. Pada tahap reduksi data ini, data yang telah diklasifikasikan kemudian diseleksi untuk memilih data yang berlimpah kemudian dipilah dalam rangka menemukan fokus penelitian.

2) Penyajian Data

Penyajian adalah menampilkan informasi tersusun yang memberi kemungkinan adanya penarikan kesimpulan dan pengambilan tindakan. Data-data yang telah tersusun kemudian disajikan dalam bentuk analisis sehingga akan tergambar permasalahan yang menjadi objek kajian.

3) Penarikan Simpulan

Teknik penarikan simpulan adalah langkah yang esensial dalam proses penelitian. Penarikan simpulan ini didasarkan atas pengorganisasian informasi yang diperoleh dalam analisis data. Penarikan simpulan dalam penelitian ini menggunakan teknik induktif, yaitu teknik penarikan simpulan dari data-data yang bersifat khusus menuju simpulan yang bersifat umum.

\section{HASIL DAN PENELITIAN}

1) Mekanisme Pertanggungjawaban Objek Gadai Nasabah di PT. Pegadaian Cabang Panakkukang Kota Makassar

Hasil penelitian yang penulis lakukan di kantor PT. Pegadaian Cabang Panakkukang Kota Makassar dengan mewawancarai beberapa pegawai kantor tersebut menghasilkan pengetahuan baru tentang proses pelaksanaan kredit dengan jaminan gadai di PT. Pegadaiaan (Persero).

PT. Pegadaian merupakan salah satu perusahaan milik pemerintah yang memberikan pinjaman dengan sistem gadai. Slogan mereka yang berbunyi "menyelesaikan masalah tanpa masalah" mengandung maksud kurang lebih yaitu, seseorang bisa mendapatkan pinjaman secara cepat untuk menutupi kebutuhan keuangan, dan besarnya pinjaman yang diterima tergantung nilai taksir dari jaminan. Barang jaminan bisa berupa, elektronik perhiaan dan kendaraan mobil atau motor dengan 
menggadekan buku kepemilkan kendaraan (BPKB).

Saat ingin meminjam uang di pegadaian ada beberapa syarat dan tahapan yang harus dilalui. Nasabah bisa langsung datang ke pegadaian dengan membawa barang yang dijadikan jaminan. Barang jaminan tersebut akan diteliti kualitasnya untuk ditaksir dan di tentukan harga. Setelah ditaksir, kasir akan memberikan pinjaman sebesar nilai taksir jaminan, tanpa ada potongan kecuali potongan premi asuransi.

Pada dasarnya, prosedur dalam peminjaman dan pelunasan kredit gadai sangant praktis karena di dalam peminjaman dan pengembalian kredit tidak memerlukan birokrai yang panjang, karena tidak melibatkan instansi yang lainya. Peminjaman kredit konstruksi gadai ini hanya melibatkan lembaga pegadaian semata-mata. (Salim HS, 2014:43).

Ketentuan mengenai pemberian kredit gadai pada PT. Pegadaian Cabang Panakkukang Kota Makassar akan diuraikan yaitu dengan cara pihak pegadaian selaku debitur dapat langsung memberikan pelayanan kredit gadai bagi nasabah dengan syarat permintaan kredit sebagai berikut:

1) Syarat-syarat pemberian kredit gadai oleh kantor PT. Pegadaian sebagai berikut:

a) Menyerahkan foto copy KTP atau kartu pengenal lain (SIM, Paspor) yang masih berlaku, dengan menunjukkan asliny

b) Menyerahkan barang jamina

c) Mengisi Formulir Permintaan Kredit (FPK) dan menandatanganiny

d) Memilih jangka waktu kredit yang dikehendakiny

e) Menandatangani perjanjian pinjaman pada Surat Bukti Kredit (SBK

f) Membayar Biaya Administrasi (BA)Khusus untuk barang jaminan

g) Kendaraan bermotor dilengkapi dengan persyaratan lainnya yang diatur dalam SE tersendiri.

Bagi pihak PT. Pegadaian, untuk menjaga keamanan dari kredit yang disalurkan, mengharuskan adanya penyerahan barang jaminan dari nasabah kepada pihak pegadaian. Dengan diserahkannya barang jaminan, maka keamanan kredit akan terjaga sebab apabila nasabah tidak dapat melunasi hutangnya pihak pegadaian mempunyai hak untuk mengambil pelunasan hutang nasabah dengan jalan melelang jaminan.
Dengan dikuasainya barang jaminan milik nasabah dibawah penguasaan langsung pihak pegadaian, maka sesuai dengan asas pihak pegadaian harus menjaga keamanan dan pemeliharaan barang jaminan tersebut. Dengan demikian apabila barang jaminan milik nasabah mengalami kerusakan atau hilang, pihak pegadaian berkewajiban untuk memberikan ganti kerugian.

Langkah-langkah yang dilakukan pihak pegadaian, agara barang jaminan nasabah tidak mengalami kerusakan atau hilang, menetapakan ketentuan sebagai berikut:

a) Dalam Pasal 13 ayat (1) Aturan Dasar Pegadaian, ditetapkan bahwa pihak pegadaian berkewajiban untuk menyimpan dan memelihara barang jaminan sebaikbaiknya, sehingga tidak rusak atau turun harganya;

b) Pasal 25 ayat (2) Buku Tata Pekerjaan Pegadaian, mengharuskan setiap orang yang akan masuk gudang penyimpanan didampingi oleh pemegang gudang;

c) Pasal 25 ayat (10) Buku Tata Pekerjaan Pegadaian, tidak memperkenankan siapa saja ada didalam gudang untuk merokok agar tidak terjadinya kebakaran;

d) Pasal 25 ayat (14) Buku Tata Pekerjaan Pegadaian menerangkan bahwa, barang yangtidak disimpan dalam lemari besi harus selalu dibersihkan oleh petugas gudang. Untuk mencegah adanya kerusakan barang jaminan misalnya cash laptop oleh binatang kecil seperti rayap, tikus maka gudang harus secara teratur disemprot dengan insektisida;

e) Pasal 16 ayat (1) Buku Tata Pekerjaan Pegadaian, mengharuskan adanya (3) buah alat pemadam kebakran dilengkapi dengan isi cadangannya dan alat tersebut ditaruh ditepat yang mudah dijangkau;

f) Pasal 16 ayat (4). Buku tata pekerjaan pegadaiaan menyebutkan, bahwa kantor cabang yang mendapatkan musibah kebakaran maka yang wajib diselamatkan adalah buku pokok yang masih digunakan semua uang dan isi peti besi, Surat Bukti Kredit, buku lainnya, dan barang jaminan.

\section{Pembahasan}

Perjanjian gadai pada PT. Pegadaian (Persero) menggunakan syarat-syarat baku sebagai dasar perjanjian dalam pemberian dana kepada nasabah. Dari sisi hukum perjanjian, syarat-syarat baku yang dibuat PT. Pegadaian (Persero) merupakan salah satu bentuk 
perjanjian yang sah jika pihak kreditur dan debitur menjadikan kesepakatan sebagai instrument hukum dalam pemenuhan hak dan kewajiban para pihak.

Terwujudnya kesepakatan diketahui dari terbitnya bukti tertulis (dalam hal ini Surat Bukti Kredit selanjutnya disebut SBK). Disepakatinya surat perjanjian dalam bentuk tertulis, diartikan sebagai suatu wujud kesepakatan yang sesuai dengan acuan teoritis tentang persesuaian kehendak. Keberadaan perjanjian atas jaminan gadai antara Pegadaian sebagai kreditur dengan nasabah sebagai debitur berfungsi sebagai hukum dan mengikat para pihak demi adanya kepastian hukum bagi para pihak. Dalam Peraturan Direksi No 5 Tahun 2014 tentang Satuan Operasional Pegadaian untuk kredit cepat dan aman (KCA) menentukan bahwa bukti kepemilikan barang jaminan (BJ) dibagi menjadi:

1) Bukti kepemilikan untuk BJ yang terdaftar pada Register Negara yaitu bukti kepemilikan barang yang dikeluarkan oleh instansi yang berwenang menurut perundangg-undangan yang berlaku, misalnya kendaraan bermotor dibuktikan dengan adanya BPKB (Bukti Pemilik Kendaraan Bermotor) dan bukti lainnya.

2) Bukti kepemilikan untuk BJ yang tidak terdaftar pada Register Negara, maka untuk BJ jenis ini berlaku ketentuan pasal 1977 KUH Perdata yaitu terhadap benda bergerak yang tidak berupa bunga maupun piutang yang tidak harus harus dibayar kepada si pembawa, maka barang siapa yang menguasainya dianggap sebagai pemiliknya, misalnya : emas, berlian,alat elektronik dan sebagainya. Si berpiutang (penerima gadai) adalah pihak yang bertanggung jawab atas hilangnya atau merosotnya harga barangnya yang terjadi karena kelalaiannya, sebaliknya si berhutang diwajibkan mengganti kepada si berpiutang segala biaya yang berguna dan perlu yang telah dikeluarkan oleh pihak yang tersebut belakang ini guna keselamatan barangnya gadai, sebagaimana diatur dalam Pasal 1157 KUH Perdata. Dasar hukum yang mengatur mengenai ganti rugi dalam perjanjian kredit gadai di lingkungan PT. Pegadaian (Persero) terkait dengan risiko diatur dalam Aturan Dasar Pegadaian (Stb. 81 Tahun 1928) dan Buku Tata Pekerjaan Pegadaian (Keputusan Kepala Perusahaan Jawatan Pegadaian No.Pr.2/4/45/1981) dan yang sekarang juga sudah ada tambahan Surat Keputusan dari Pusat.

Menurut Pasal 13 ayat (2) Aturan Dasar Pegadaian, menyatakan bahwa PT. Pegadaian (Persero) menanggung risiko segala kerusakan pada barang-barang gadai yang terjadi karena kebakaran atau karena sebab lain yang dapat diduga menjadi penyebab kerusakan atau kehilangannya, tetapi jikalau barang turun harganya sebab tidak dirawat tiap hari maka si pemberi gadai tidak ada hak untuk minta ganti rugi.

Penetapan besarnya ganti kerugian adalah juga ada yaitu sebesar $125 \%$ (persen) dari harga taksiran atas nilai barang gadai yang bersangkutan, hal ini didasarkan pada ketentuan dalam Pasal 13 ayat (3) Aturan Dasar Pegadaian Jo Pasal 6 ayat (4) Buku Tata Pekerjaan Pegadaian. Apabila hanya mendasarkan atas penetapan besarnya uang pinjaman yaitu untuk golongan A dan B besarnya $80 \%$ (persen) dari harga taksiran, sedangkan untuk golongan $\mathrm{C}$ adalah $89 \%$ (persen) dari harga taksiran dan untuk golongan D adalah sebesar $85 \%$ (persen) dari harga taksiran.

Mengenai besarnya ganti kerugian pada PT. Pegadaian (Persero) telah ditetapkan sebesar $125 \%$ (persen) dari harga taksiran. Adapun jangka waktu untuk mengajukan kerusakan adalah pada saat penerimaan barang gadai dari pihak penerima gadai kepada pihak pemberi gadai, sedangkan untuk pembayaran ganti kerugiannya adalah didasarkan hanya atas kerusakan yang ada pada barang gadai, untuk besarnya ganti kerugian tersebut juga sama dengan tersebut di atas yaitu $125 \%$ (persen) dari harga taksiran terhadap bagian yang rusak.

Terkait barang-barang yang dimiliki pemberi gadai yang telah dijaminkan pada pemegang gadai PT. Pegadaian Cabang Panakkukang Kota Makassar untuk menghindari adanya risiko kerugian, hendaknya perlu dijaga keamanan serta perawatan terhadap barang jaminan yang akan diserahkan kembali kepada pemberi gadai, karena telah melunasi hutangnya.

Agar barang jaminan tidak mengalami kerusakan atau hilang, maka pihak PT. Pegadaian Cabang Panakkukang Kota Makassar telah menetapakan ketentuan sebagai berikut:

a) Dalam Pasal 13 ayat (1) Aturan Dasar Pegadaian, ditetapkan bahwa pihak Pegadaian berkewajiban untuk menyimpan dan memelihara barang jaminan sebaikbaiknya, sehingga tidak rusak atau turun harganya; 
b) Pasal 25 ayat (2) Buku Tata Pekerjaan Pegadaian, mengharuskan setiap orang yang akan masuk gudang penyimpanan didampingi oleh pemegang gudang;

c) Pasal 25 ayat (10) Buku Tata Pekerjaan Pegadaian, tidak memperkenankan siapa saja ada didalam gudang untuk merokok agar tidak terjadinya kebakaran;

d) Pasal 25 ayat (14) Buku Tata Pekerjaan Pegadaian menerangkan bahwa, barang yang tidak disimpan dalam lemari besi harus selalu dibersihkan oleh petugas gudang. Untuk mencegah adanya kerusakan barang jaminan misalnya cash laptop oleh binatang kecil seperti rayap, tikus maka gudang harus secara teratur disemprot dengan insektisida;

e) Pasal 16 ayat (1) Buku Tata Pekerjaan Pegadaian, mengharuskan adanya (3) buah alat pemadam kebakran dilengkapi dengan isi cadangannya dan alat tersebut ditaruh ditepat yang mudah dijangkau;

f) Pasal 16 ayat (4). Buku tata pekerjaan pegadaiaan menyebutkan, bahwa kantor cabang yang mendapatkan musibah kebakaran maka yang wajib diselamatkan adalah buku pokok yang masih digunakan semua uang dan isi peti besi, Surat Bukti Kredit, buku lainnya, dan barang jaminan.

Disisi lain bentuk perawatan yang dilakukan oleh PT. Pegadaian terhadap objek gadai nasabah adalah sebagai berikut:

a) Untuk barang yang berbeda akan dipisahkan dan ditempatkan pada tempat yang berbeda, hal ini dilihat dari sisi ukuranya, penggunaanya dan ekonomisnya.

b) Untuk benda yang berbeda akan beda pula perawatannya, karna ada barang tertentu yang perlu mendapatkan perawatan khusus.

c) Akan dilakukan pengeceka setiap hari dan dilakukan pembersihan beberapa kali seminggu.

\section{SIMPULAN DAN SARAN}

PT. Pegadaian Cabang Panakkukang Kota Makassar bertanggung jawab untuk menanggung risiko dalam hal terjadi kerugian yang menimpa nasabah atas barang jaminan gadai. Ganti kerugian yang diberikan oleh PT. Pegadaian (Persero) adalah sesuai kerusakan barang tersebut dan dihitung dari harga taksiran barang jaminan atau dengan kesepakatan bersama dan itikad baik, sedangkan untuk menentukan adanya kerugian yang disebabkan oleh adanya Force Majeure tidak dapat dilakukan sendiri oleh PT. Pegadaian (Persero), tetapi penentuannya harus oleh PT. Pegadaian (Persero) Pusat ataupun dilakukan oleh Pejabat Pegadaian.

Pemeliharaan objek gadai nasabah di PT. Pegadaian Cabang Panakkukang Kota Makassar sebagai berikut:

a) Untuk barang yang berbeda akan dipisahkan dan ditempatkan pada tempat yang berbeda, hal ini dilihat dari sisi ukuranya, penggunaanya dan ekonomisnya.

b) Untuk benda yang berbeda akan beda pula perawatannya, karna ada barang tertentu yang perlu mendapatkan perawatan khusus.

c) Akan dilakukan pengeceka setiap hari dan dilakukan pembersihan beberapa kali seminggu.

d) Umumnya untuk penjagaan objek gadai nasabah sudah diatur dalam buku pedoman PT. Pegadaian.

\section{DAFTAR RUJUKAN}

Abd. Shomad, (2010) Hukum Islam, Jakarta: Kencana.

Kadir \& amp; Rilda Murniati (2000). "Segi Hukum Lembaga Pembiayaan dan Keuangan", Bandung: CitraAdityaBakti.

Antonio, Muhammad Syafi'i. (2001). Bank Syariah dari Teorike Praktek, Jakarta, Gema Insani Press.

Denny Prihartanto (2015).Tanggung Jawab PT Pegadaian Terhadap Kerugian Atas Rusak Atau Hilangnya Jaminan Di PT. Pegadaian-Jurnal ilmiah Fakultas Hukum Universitas Slamet Riyadivol.01 juli-desember. Hal 155-162.Surakarta

Evi Lutfiana Dewi (2017). Tanggung jawab Pegadaian Syariah Atas Hilang Atau Rusaknya Barang Jaminan Dalam Perspektif Hukum Islam

Jurnal Syari'ah vol. 1 Januari-Juni. Hal 98-107 Universitas Islam Negeri Raden Intan Lampung.

Kartini \& amp; Gunawan, (2006), Hak Tanggungan. Jakarta: Prenada Media,

Kartini Muljadi \& amp; Gunawan Widjaja, (2006), .Hak Istimewa, Gadai dan Hipotek, Bandung, Sinar Grafika,

Manahan P. Tampubolon, (2004), Manajemen Operasional (Operation Management), Jakarta: Ghalia Indonesia.

Manan Abdullah, (1995).Islamic Economic: Theoryand Practice, Delhi. ShM. Ashraf. 
Phinisi Integration Review. Vol 2(2) Agustus 2019

Misuari (2016).Mekanisme Pertanggung Jawaban Terhadap Objek Gadai Oleh Pegadaian Syariah Ditinjau Menurut Fiqh Muamalah (studi kasus pada pt. Pegadaian syariah kabupaten aceh besar cabang Keutapang). Jurnal Syari'ah Dan Hukum Universitas Islam Negeri ArRaniry Darussalam, Banda Aceh. Hal 7684.

Milles Matthew B \& amp;Michael Hubberman (2014). Analisis data penelitian kualitatif. Jakarta: UI Pres. 